\title{
Finding sonnets about sand: using local voices in literature classrooms
}

\author{
Marielle R. Risse \\ Dhofar University, Oman
}

To help students who live outside important centers of literary production feel more connected to their introduction to literature classes, I believe it is important to create 'local-relevant' syllabi. The purpose of this paper is to discuss how to construct syllabi which reflect students' geographical position. In doing this, I will give examples of pairs of Western and Middle Eastern poems, short stories and plays which can be taught together to connect two geographical areas usually known more for their differences than their similarities.

There are three steps to fashioning local-based syllabi. Firstly, use some canonical authors who have written something that can be connected to the regional situation. Secondly, add one or two local authors, even if the literary quality is slightly uneven. Thirdly, create compare and contrast pairs between an established writer and a local writer.

Teaching literature always means attempting to balance literature "about us" with literature "about them." In Salalah, Oman, where I teach now, and in Grand Forks, North Dakota, where I taught before, the writing that shows up in literature classrooms is almost always "about them," i.e. other communities or nationalities. Quality writing is seen as something created elsewhere and consumed, as often as not, with reluctance. There is a school of thought that argues "good literature is universal", but I believe teachers should bring novice literature students into the conversation by helping students see their own lifeways depicted in texts.

Finding the balance between celebrating what is foreign and what is familiar to "empty" lands is both difficult and necessary because students often don't believe literature written "here" or "about here" has any literary worth. Teresa Howell, a friend teaching in Winnemucca, Nevada, tells me that one of her students was surprised to find herself enjoying an excerpt from Mark Twain's Roughing It, saying "It's about Nevada, and that means it's technically boring."

The issue is exacerbated for me in that I teach English literature to Omani students at Dhofar University, located in Salalah, Oman, a small town on the coast of the Arabian Sea. The border with Yemen is about $1 \frac{1}{2}$ hours' drive west, the border with Saudi Arabia is about 2 hours' drive north. The classrooms are mixed, but men and women sit separately and do not interact with each other. Students are intelligent but their level of English tends to be low because there are few opportunities for students to speak, read or listen to English outside of the English classroom.

Given that many of our students either will not work or will work in a family business, their course work may not have a significant impact on their life. I therefore try to make the literature classes as varied as possible, to try to spark an interest in poetry or novels. In American universities, literature classes need to convey basic content about time periods, style, mode and norms; in Salalah, literature classes are more a way to practice speaking, reading and writing English. 
Thus in one introduction to poetry class, I taught a variety of 15 poems, including Shakespeare's "All the world's a stage" speech; "Summer" by John Clare; "Song" by Alfred, Lord Tennyson; "Sonnet" by Sir John Suckling; "A Beautiful Mistress" by Thomas Carew; two sonnets by Spenser; and poems by Dorothy Parker, Donald Justice, Tom Wayman, Robert Phillips, Cavafy, and Mohja Kahf, a Syrian woman currently living in the US.

This selection reflects my three-fold approach to creating literature syllabi. First, find texts by canonical authors which have a local relevance. Then I add one or two local writers to create compare and contrast pairs between an established writer and a local writer. I use this system to teach in three different areas of literature: poetry, short stories and plays.

I would like to discuss a few poems first to show the kind of difficulties that cross-cultural misunderstandings may cause. A friend recommended "Painting a Room," by Katia Kapovich as being really successful with her students. The second stanza begins "An immigration visa in my pocket, I paint the small apartment where I've lived for ten years." Her American college students relate to the poem, comparing it to their experiences of leaving their bedroom/ home to go to college, but all of my students live at home. The boys continue to live with their parents after marriage and "visas" are usually an occasion of sadness, not new hope. Living abroad for some students is a dream, but most see it as a necessary evil to go overseas, get specialized knowledge or medical treatment, then quickly return home.

Many 'great' poems such as "Ode on Solitude" by Alexander Pope or "The Lake Isle of Innisfree" by William Butler Yeats don't resonate in Oman; for example:

Thus let me live, unseen, unknown;

Thus unlamented let me dye;

Steal from the world, and not a stone

Tell where I lie.

and:

I will arise and go now, and go to Innisfree,

And a small cabin build there, of clay and wattles made:

Nine bean-rows will I have there, a hive for the honeybee,

And live alone in the bee-loud glade.

Living alone would be difficult for my social, family- and tribe-oriented Omani students. No one would choose willingly to live outside the family structure. The whole Romantic, back-to-nature era and poetic expression is bewildering for students. "No AC?" they ask, horrified, as their framework of nature is not a sylvan glade but a burning desert, 130 degree heat choking you. I taught "Lake Isle" as a way to show not so much the purity of the rhyme, meter and metaphor but of an expression of a completely different way to view the world.

Then I added poems such as "The Camel" by Ogden Nash, "The Camel's Complaint" by Charles E. Carryl and Babette Deutsch's "The Gazelle" to show how an animal common and familiar to my students can be reconfigured into poetry. As the hospital has an ultrasound machine, I taught Thomas Lux's "Upon Seeing an Ultrasound Photo of an Unborn Child." My students really enjoyed that poem, giggling away at the father teasing his child. 
"The Passionate Shepherd to His Love" by Christopher Marlowe works well, as it uses various words which connect to Oman: "valley," "rocks," "shepherds," "flocks of sheep," "roses" (grown on Jebel Akhdar), "gold," "coral," and "amber." "She Walks in Beauty" by Lord Bryon is a great poem to teach in the Gulf as it is about a woman with dark hair and dark eyes. As some of my students' grandfathers traded with India, sailing across the Indian Ocean, I use Edmund Spenser's Sonnet 15. The basic principle is easy: the narrator is asking merchants "Why do you make yourself tired going to India for treasure when all the treasure in the world is here, in the form of my wife, who has every kind of outside beauty, crowned with a virtuous mind".

Finding Western poems to teach is not that difficult, but flipping through short story anthologies is usually an exercise in futility. The basic parameters are: no explicit sexual content, little or no alcohol, no drugs, not a lot of religious discussion and no politics, especially Middle Eastern politics. But the real problem is that many modern Western writers use sarcasm, irony and disillusion/ dissatisfaction (cf. Moody, 2010). I taught John Cheever's "The Swimmer" to try to explicate symbolism, over-arching metaphors, foreshadow and unresolved endings. However, my students were confused from beginning to end: Why weren't the neighbors helping the man? Why didn't every person he met invite him in? Why was he swimming alone? Why weren't his friends with him? Why did he leave his wife at the party? The whole underlying structure of a man alienated from his environment - easy to understand from an American point-of-view - was incomprehensible to my students. They hated the story and viewed the ending as moralistic, "He drank alcohol, so of course his wife left him. She went back to her father and asked for a divorce."

"The Ones Who Walk Away from Omelas" (Le Guin, 1975), another staple of Freshman Literature classes also confused them. "Is this real? Where is this city?" they asked, unused to indirect social criticism. The conceit that the happiness of the city was based on one child's unhappiness was ridiculous to them. "Let the child out," they said, "then they work together and the city will be nice." The idea that someone suffers to create the peaceful atmosphere doesn't make sense.

On the other hand, "Story of an Hour" by Kate Chopin is an old chestnut that works well, especially for the married women students; they narrow their eyes and nod wisely. "Girl" by Jamaica Kincaid, a very short story made up of series of commands from a mother to a daughter, works perfectly. I asked the students to come up with their own version of the text, which they did with great amusement.

"Everyday Use" by Alice Walker also translated perfectly. A simple country woman whose two daughters, one who lives with her and one who has moved to the big city, fight over a family heirloom quilt. The city daughter wants to preserve the quilt by hanging it on a wall, arguing that the other daughter would simply 'use' the quilt and thus wear it out. The mother finally decides to let the daughter who lives with her keep the quilt. The students could relate to the issue of preserving or using family artifacts, writing about the khanjar (dagger), mandoss (wooden chest), gold necklaces, and dresses that were their own family's treasures.

"Going to Shrewsbury" by Sarah Orne Jewett, about an old woman moving from the simple house she has lived in all her life to the big city to live with nieces, is another much-anthologized piece which works well as some of my students have grandparents living in difficult circumstances in the mountains. The younger generation pleads with the elders to come live in town, with all its amenities, but the elders refuse.

When choosing a play, the rule is: old is best. It's always good to throw in a Shakespeare because it is a name the students know - a recognized quantity and, more importantly, sanctified by custom. But when I taught a class on Shakespeare (Much Ado about Nothing, Romeo and Juliet, and Midsummer's Nights 
Dream), the students' most frequent remarks were "I thought I knew this story!" and "This is difficult!" They had a basic equation in their heads: Shakespeare = good writing and Good writing = easy. They were utterly confounded to find that he has the temerity to be both "good" and difficult (all those metaphors!).

That Romeo and Juliet would have an intricate plot utterly floored them. "I thought they just fall in love and die," wailed one student confronted with a slew of characters, settings, acts, scenes, and motivations. "He's writing about all different kinds of love," I tried to explain. The students were not impressed. Their respect for "Shakespeare" continued, but their actual admiration waned in the face of his complexity of language and characterization.

Oscar Wilde is more to their taste; they adored The Importance of Being Earnest and Lady Windermere's Fan. For less advanced English students, Peter Pan was a big hit; it was really fun to work on our 'pirate voices' and since military ships dock regularly at Salalah Port to protect ships headed for the Suez Canal from being attacked, pirates are a familiar entity. However, social expectations are omnipresent: Algernon and Jack in The Importance of Being Earnest were deemed by most of the students to be 'bad examples' for not being serious enough; and Wendy, Peter and Michael in Peter Pan should have listened more to their parents.

The second part of constructing syllabi is to find local voices, and in terms of Arabic poetry a person is spoilt for choice: even just looking at the poems translated into English, there are hundreds of excellent examples. I have used The Literature of Modern Arabia: An Anthology (Jayyusi, 1988); World Poetry (Washburn, 1998); Post-Gibran: The Anthology of New Arab-American Writing (Akash, 1999); Inclined to Speak: An Anthology of Contemporary Arab-American Poetry (Charara, 2008); as well as individual collections such as E-mails from Scheherazade (Kahf, 2003); These are not Oranges, my Love (Mersal, 2008) and Flawed Landscape (Elmusa, 2008).

To mention a few of my student's favorites: "A Pearl" and "Butterflies" by Fawziyya Abu Khalid; "The Poet and the Moth" by Ahmad Qandeel and "From the Road" and Muhammad al-Shurafi. The description in Kahf's "Voyager Dust" of a woman washing her sheila (pronounced: "shay-la", the sheer black scarf women wear to cover their hair) produced smiles and laughs of recognition. The narrator explains holding out the georgette cloth to shake the water out and the female students started chatted excitedly, miming the action.

It is easy to find poems which celebrate the Bedu tradition of strength and independence, such as " $\mathrm{A}$ Page from a Bedouin Notebook" by Muhammad Al Thuhaiti and the "The Black Knight" by Antara and the very famous "The Mu'allaqa" poems by Labid Ibn Rabia and Shanfara. However, my students from Salalah were nonplussed when I found a poem in the local, unwritten, language (Gibali) that had been phonetically reproduced and then translated into English. Such a poem was deemed unimportant and not 'real' literature. But the minority of students in the class who spoke this language at home, were thrilled that what was often dismissed as "the language of birds" was studied and honored by being given a place in a university setting. "Local" as Arabic was deemed worthy, but "local" as in from the mountains was not acceptable as "real" literature.

A colleague and I working together translated a poem written by a local author in Arabic about the mountains outside of town. It was useful for me to be at a cultural disadvantage, to remember what it means to grope through unintelligible metaphors. I gave my students the poem in Arabic and English. After we worked though the English version, my students asked if they could please read it in Arabic. Well, of course, I said. And their voices took off, light, skimming over the words, perfectly in unison. Freed from the constraints of English, it was like watching someone take off heavy chains and finally 
have the freedom to dance. They enjoyed it so much - when they got to the end, they went back and read it straight through again.

Finding local stories is also fairly easy in the Middle East. When in doubt one can always go to the maître: Naguib Mahfouz. There are also the famous collections by Emirati author Mohammed Al Murr, The Wink of the Mona Lisa (1998) and Dubai Tales (2008). My students sympathized with the woman in "Dancing by the Light of the Moon" by Salih Saeed Ba-Amer, who has to marry the man her father chooses. As the story is set in a small village in Yemen, it felt familiar to my classes. Similarly, "The Slave Fort" by Ghassan Kanafani is a story of two friends who go on a picnic by the sea. This is a common activity in Salalah so even though the story in not set in Oman, the students could envision taking the equipment out of the car, building a fire for tea etc.

Drama has a less established tradition in Middle Eastern literature, so there are comparatively fewer choices. I have used Tawfiq Al Hakim's (1981) "Princess Sunshine" to great success. It takes the Disney trope of the princess waiting for her prince and turns it on its head. The prince is not charming at all; he challenges her spoiled brat life, leads her out of the palace and makes her cook her own dinner over a campfire. Then, when the two begin to understand each other and fall in love, he decides to continue his travels. She will return back to her palace to reform the government system from within to be more fair and responsive to the citizens. Take that, Snow White, Cinderella, Sleeping Beauty, The Little Mermaid and Belle!

The third component of constructing syllabi is to match local and more established writers. Again, this is simple with poetry as there are so many choices, especially with garden motifs. For example Nedim's "Take Yourself to the Rose-Garden" works perfectly with Herrick's "Corinna's Going A-Maying": "Come rose-mouthed one, your nightingales are calling" warbles Nedim's narrator; "Rise and put on your foliage, and be seen/ To come forth, like the springtime, fresh and green," echoes Herrick's narrator.

Herrick is usually taught in relation to other English poets, e.g. John Clare's poems of rural life. But living an hour's drive from the Empty Quarter (250,000 square miles of desert) means that my students will relate Clare's poem "July" not back to the English Herrick but to their own world. "Till noon burns with its blistering breath/ Around, and day dies still as death", crickets, flies, a landscape that "sleeps", "ovenheated air" and the "joy" of sunset are familiar to them. They are not reading a 'foreign' poem but a familiar poem which happens to be in English.

The linking of heat and death (instead of, for example, heat and love) is normal to my students. Teaching John Clare allows me to bring in an English poet who is speaking their metaphorical language. For example "July" pairs perfectly with Ahmed Muhammad Al Khalifa's "The Deserted Valley", which begins "I came to it when the valley flowers were withered"; with Abdalla Muhammad Jabr's amusing "The Bursting out of Summer", whose second stanza begins "Tell the heat to spare me/ until another day"; or with Ibrahim Al-Hadrani's "The Fountain." The recurring motifs of a spring that is dead, the heat that kills and the joy/ peace/ safety of night cross back and forth between $19^{\text {th }}$ century England and the $21^{\text {st }}$ century Arabian Peninsula.

I have many students whose family members are shepherds for flocks of goats or who herd the camels home every evening. Clare's "Summer Morning" is, to them, an accurate description of a daily event with the "village-spire" translating into a minaret. Thus, John Clare bridges the gap between what my students know to be true and what they perceive as 'alien' English/ Western culture.

Given the importance of the sea in Gulf life, using poems that focus on sailing sparks the students' interest. For example "A Sailor's Memoirs" by Muhammad Al-Fayiz works well with "Sea-Fever" by John 
Masefield. "Your salt is more delicious than the grapes of the city" writes al-Fayiz; while Masefield writes: "I must down to the seas again, to the lonely sea and the sky."

"The Rider" by Qasim Haddad and "The Highwayman" by Alfred Noyes are another pair which connect to the life of brigands in the Gulf and England in previous time periods. "Welcome rider, highwayman," says the Bedouin narrator of Haddad's poem. The narrator agrees to share his fire, clothes and horses, but warns the rider that justice, in the form of caravans "come for you". Similarly, the robber in Noye's poem faces justice in a thrilling narrative.

There are thousands of love poems in English and Arabic, but when you can find two with matching metaphors, you can start to make the poems "talk to each other", for example "Clouds" by Sulaiman Al-Fulayyih and "Some Clouds" by Steve Kowit. Both poems use clouds as a controlling metaphor for grief, but Al-Fulayyih refers to an unnamed universal grief while Kowit is more specific, the death of a former love.

In the same way, "Love's Wounds" by Abdullah Al-Faysal, "Fountain" by Ibrahim Al-Hadrani and "When We Two Parted" by Lord Byron work as a mini-unit on the theme of a love that has died. Al-Faysal writes "Ask not of love's tears when love has departed far away", Al-Hadrani writes "First we meet, then we part" and Lord Bryon begins his poem with "When we two parted, In silence and tears". "The Lost Mirage" and "The Deserted Valley" (Ahmad Muhammad Al-Khalifa) and "Stanzas Written in Dejection, near Naples" (Percy Bysshe Shelley) all focus on the idea of water and grief. The narrator of "The Lost Mirage" sees water that doesn't exist; in "The Deserted Valley" and "Stanzas" the despondent narrator compares beautiful, water-filled scenery with the metaphorical desert in his heart. "I... am lost in my own country" complains Al-Khalifa; "Alas! I have nor hope nor health/ Nor peace within nor calm around," grumbles Shelley.

To get away from standard love poems, I like to find matching poems on different relationships. For example, "Death in Life" by Ahmad Qandeel and "On My First Daughter" by Ben Jonson are two poems separated by centuries and continents, which show the grief of a father who has lost his daughter.

I use "Sojourn Forever", "Free Harbor" and "You Alone" by Suad al-Mubarak al-Sabah together with "A Birthday" by Christina Rossetti. "Sojourn Forever" and "A Birthday" both have the metaphor of a woman in love being "on a throne", while "Free Harbor" and "A Birthday" use metaphors of ships to show the happiness of shared love: "Your ships alone have the right to sail in my blood" trills the narrator of "Free Harbor"; "My heart is like a rainbow shell/ That paddles in a halcyon sea" echoes the narrator of "A Birthday".

In choosing short stories, I can pair well-known "surprise" short stories such as "The Necklace" by Guy de Maupassant or "The Gift of the Magi" by O. Henry with the Emirati author Mohammed al Murr's "The Wink of the Mona Lisa": a boy falls in love with one of his sister's friends at the sister's wedding because she winks at him; he (as traditional) sends his mother and sisters to meet her and her family; his mother begs him to pick another girl with closer ties to his family but he insists on his choice.

The students enjoyed condemning the shameless woman for such blatant behavior as winking at a strange man, until the last paragraph of the story when the happy protagonist, wedded to the 'wanton' woman, confesses to his new wife that is was her wink that stole his heart. Startled, she thinks back to the night of her friend's wedding, the new contact lens that hurt her eyes, and decides not to tell her husband that she never even noticed him that evening. A sadder surprise short story is "The Persian Carpet" by Hanan Shaykh in which a girl realizes her adored mother gave a carpet to her lover, but blamed a poor man in the neighborhood. 
The dissipated, world-weary view expressed in "Another Evening at the Club" by Alifa Rifaat is a good companion-piece to "The Great Gatsby" or a F. Scott Fitzgerald short story such as "Babylon Revisited." "Love and Rain" by Muhammad Alwan about a boy's failed attempt to impress a female classmate is the Arabic equal to James Joyce's "Araby." "I Saw the Date Palms" by Radwa Ashour pairs with "A Death in the Woods" by Sherwood Anderson in that they are both stories about women without status or power, using the imagery of trees.

As mentioned, there are fewer plays in the Arab tradition. One useful dialogue I have found is the book The Arab Oedipus (Carlson, 2005) which collects four versions by Arab authors of the canonical Western story. The Comedy of Oedipus by Ali Salim is wonderful; Oedipus doesn't actually kill the Sphinx, but as the action happens out of sight of the citizens and the Sphinx disappears, he is celebrated for his achievement. He wonders through most of the play how he can tell the citizens, who hasten to buy 'Oedipus Killed the Beast' action figures.

I would never argue that syllabi should be solely dependent on local works, but to give students something familiar when starting their literature adventures makes the transition from simply reading to analyzing easier. On the other hand, including texts from 'away' is also necessary. It is one thing to talk about the need for intercultural exchanges; it is another, in the midst of teaching, grading, doing research, publishing, committee work and maintaining a personal life, to expand one's areas of expertise. I hope this essay confirms the need for some local-based texts to be included in Introduction to Literature syllabi, as well as offering English teachers (and perhaps teachers of other disciplines) some suggestions for including Middle Eastern material in the university classroom.

\section{Bibliography}

\section{Poetry}

Charara, H. (Ed.). (2008). Inclined to speak: An anthology of contemporary Arab-American poetry. Fayetteville, AK: The University of Arkansas Press.

Elmusa, S. (2008). Flawed landscape: Poems 1987-2008. Northampton, MA: Interlink.

Kahf, M. (2003). E-mails from Scheherazade. Gainesville, FL: University Press of Florida.

Handal, N. (Ed.). (2001). The poetry of Arab women: A contemporary anthology. New York: Interlink.

Kabbani, N. (1999). Arabian love poems. (B. K. Franieh and C. R. Brown, Trans.). London: Lynne Rienner.

Mersal, I. (2008). These are not oranges, my love. Riverdale, NY: Sheep Meadow Press.

Nye, N. S. (2002). 19 varieties of gazelle: Poems of the Middle East. New York: Greenwillow.

Nye. N.S. (Ed.). (1996). This same sky: A collection of poems from around the world. New York: Aladdin.

Sells, M. (Trans.). (1989). Desert tracings: Six classic Arabian odes by Alqama, Shanfara, Labid, Antara, Al-Asha and Dhu al-Rumma. Middleton, CT: Wesleyan University Press.

Washburn, K. and Major, J. (Eds.). (1998). World poetry. New York, W.W. Norton.

Williams, D. (1993). Traveling mercies. Cambridge, MA: Alice James Books. 


\section{Short Stories}

Al-Murr, M. (1998). "The wink of the Mona Lisa" and other stories from the Gulf. (J. Briggs, Trans.). Dubai: United Arab Emirates: Motivate Publishing.

Al-Murr, M. (2008). Dubai tales. (P. Clark and J. Briggs, Trans.). Dubai: Motivate Publishing.

Husni, R. and Newman, D. (Eds.) (2008). Modern Arabic short stories: A bilingual reader. London: Saqi.

Johnson-Davies, D. (Ed.). (1994). Arabic short stories. Berkeley: University of CA Press.

Johnson-Davies, D. (Ed.). (2006). The anchor book of modern Arabic fiction. New York: Anchor Books/ Random House.

Kaldas, P. and Mattawa, K. (Eds.). (2009). Dinarzad's children: An anthology of contemporary Arab American fiction. Fayetteville, AK: The University of Arkansas Press.

Kamal, M. (1999). Juha: Last of the errant knights. (J. Briggs, Trans.). Dubai: Motivate Publishing.

Le Guin, U.K. (1975). The ones who walk away from Omelas. The Wind's Twelve Quarters. Harper \& Row.

\section{Plays}

Al-Hakim, T. (1981). Plays, prefaces and postscripts of Tawfiq Al-Hakim, Volume One. (W. M. Hutchins, Trans.). Washington D.C.: Three Continents Press.

Carlson, M. (Ed.). (2005). The Arab Oedipus: Four plays. New York: Martin E. Segal Theater Center Publications.

Zimmerman, M. (2005). The Arabian nights: A play. Evanston, IL: Northwestern University Press.

\section{Anthologies of poetry and fiction}

Akash, M. and Mattawa, K. (Eds.). (1999). Post-Gibran: The anthology of new Arab-American writing. Klagenfurt, Austria: Kitab. Published in USA in Jusoor, 11 \& 12, distributed by Syracuse University Press. Jayyusi. S. K. (Ed). (1988). The literature of modern Arabia: An anthology. London: Kegan Paul International.

\section{Secondary Sources}

Bernheiner, C. (Ed.). (1995). Comparative literature in the age of multiculturalism. Baltimore: Johns Hopkins University Press.

Hall, J. (2002). Teaching and researching language and culture. New York: Longman.

Hinkel, E. (1999). Culture in second language teaching and learning. Cambridge: Cambridge University Press.

Irwin, R. (2002). Night and horses and the desert: An anthology of classical Arabic literature. New York: Anchor.

Kiesling, S. and Paulston, C. B. (Eds.). Intercultural discourse and communication: The Essential Readings. Oxford: Blackwell.

Kramsch, C. (1993). Context and culture in language learning. Oxford: Oxford University Press. 
Moody, J. (2010). Pragmatics and the Internet in University Teaching. Learning And Teaching In Higher Education: Gulf Perspectives, 8(1). Retrieved January 8, 2012, from

http://Ithe.zu.ac.ae/index.php/Ithehome/article/view/33

Scollon, R. and Scollon, S. W. (2001). Intercultural communication: A discourse approach. Oxford: Blackwell Publishing.

Valdes, J. M. (Ed.). (1986). Culture bound. Cambridge: Cambridge University Press. 